\title{
On Variation in the Flowers of certain Species of Primula.
}

\author{
BY \\ T. G. HILL, A.R.C.S., \\ Demonstrator in Biology at St. Mary's Hospital Medical School, London. \\ With a Figure in the Text.
}

$\mathrm{M}$

$\mathrm{UCH}$ has been written concerning the Primulaceae, which in part is due to the interest taken by botanists in the morphological significance of the pistil, the position of the stamens, and origin of the petals. As regards abnormal flowers, we find that many monstrosities, \&c., have been recorded ; thus Masters ${ }^{1}$ describes cases of dialysis, meiophylly, proliferation, polyphylly, petalody of pistil and stamens, \&c.

It does not appear, however, that any detailed observations have been published as to the numerical variations of the different floral parts such as have been carried out in other natural orders, e.g., Burkill ${ }^{2}$ on Stellaria media and other plants, and Pledge ${ }^{3}$ on Ranunculus repins.

When this work was commenced some few years ago (1898) it was intended to keep under observation for a number of years one particular species of the genus gathered from

1 Masters, Maxwell, Vegetable Teratology. Ray Society, I869.

2 Burkill, I. H., On some Variations in the Number of Stamens and Carpels. Journ. Linn. Soc. Bot., vol. xxxi, I 895-7.

${ }^{3}$ Pledge, J. H., Numerical Variation of Parts of Ramunculus repens. Nat. Sci。, vol. $x, 1897$, p. 323 .

[Annals of Botany, Vo1. XVI. No. LXII. June, 1902.] 
different localities, in order to ascertain whether there obtained years of maximum and minimum variation, and also to see whether it would be possible to acquire data which would afford any indications as to the laws, if any, which govern variation.

This somewhat ambitious but excellent intention, like so many others, was not carried out, chiefly owing to the lack of time and the writer's attentions being occupied by other branches of botanical science.

But although the original scheme was practically abandoned, still several interesting facts were ascertained: so that it was resolved to tabulate and publish the somewhat fragmentary results in the hope that some interested in this line of research, and having the necessary time at their disposal, might find it possible to carry further the results embodied in this paper.

The plants used were the primrose and cowslip. The majority of the former were collected in the woods, \&c., around Stone Street, a small hamlet situated on the Lower Greensand, some four and a half miles east of Sevenoaks in Kent. Flowers were also obtained from the top of Polhill, a few miles east of Knockholt on the North Downs in the same county. The cowslips, the only other species examined in quantity, were gathered in the meadows at the foot of the North Downs, quite close to the village of Kemsing, which is again situated in Kent. Here the soil is argillaceous in character (Gault). It is almost unnecessary to add that the flowers were picked quite indiscriminately; no attempt being made to select those showing variations more than others.

The numerical variations of the outer whorls-calyx, corolla, and androecium-proved disappointing, inasmuch as they lead to no definite conclusion; hence it is proposed merely to draw attention to the more important features as briefly as possible.

Observations on the cowslips only extended over one season (1898), so that it will be as well to deal with this plant first.

Primula veris, Linn., 1898. Of this plant 1,2,50 flowers were 
examined, and of these $3.52 \%$ deviated from the normal type. The majority of abnormal flowers were heteromerous $(53.66 \%)$, and it was also seen that the short-styled flowers were more variable than the long-styled. The androecium proved the most aberrant whorl, although the total number of variations only showed a percentage of $2 \cdot 48$. The range of numerical variation in the different whorls was from 4 to 6 . The gynoecium was always normal.

It was sometimes noticed that the flowers having parts less than five in number were the youngest in an inflorescence, which corresponds to what Burkill ${ }^{1}$ found to obtain in many plants examined by him.

Primula vulgaris, Huds., 1898. The blossoms of this season were less variable than the cowslips, for out of a total of 830 , but $2.65 \%$ were aberrant. Of these variations the majority $(75 \%)$ were heteromerous, and the long-styled flowers varied slightly more than the short-styled. The range of numerical variation was the same as in $P$. veris, viz. from 4 to 6 , and the individual parts of numerically anomalous whorls of organs were generally above the normal number 5 .

The calyx was the most variable whorl, and, as before, the gynoecium was normal throughout.

1899. In the spring of this year 2,483 flowers were examined, of which number II. $3 \%$ were variable; a much higher proportion than in 1898 . The short-styled blossoms varied more than the long-styled by more than $2 \%$, and it was observed that those flowers collected during the height of the flowering season were the most abnormal. The majority $(57 \cdot 36 \%)$ were heteromerous.

As regards the range of numerical variation, it was found in the flowers of this year to be much wider than in those examined hitherto, being no less than from 3 to 8 in the case of the calyx, 4 to 8 in the corolla, and 4 to 10 in the androecium. In the long-styled flowers, taken by themselves, this range was not so wide, never being more than from 3 to 7 . Of the different whorls, the calyx varied more than the 
corolla, which in turn was slightly more aberrant than the androecium.

It has been noted that the flowers of $P$. vulgaris examined in the spring of ' 98 were all normal as regards their pistils. On the other hand, those of this year ('99) showed many interesting abnormalities: these variations, however, were confined to the styles and stigmas, in no cases were any aberrations discovered in the ovary itself.

Dealing with the stigma first; twenty-eight flowers were seen having these organs definitely lobed, while in three cases they were lobed in a more irregular manner. That is, thirtyone variations were found out of a total of over 2,000 (Table I).

TABLE I.

LOBED STIGMAS.

\begin{tabular}{|c|c|c|c|c|}
\hline & 2 -lobed. & 3 -lobed. & 4 -lobed. & $\begin{array}{c}\text { Irregularly } \\
\text { lobed. }\end{array}$ \\
\hline Short-styled flowers & 3 & 4 & 0 & 2 \\
\hline Long-styled flowers & 18 & 1 & 21 & 1 \\
\hline
\end{tabular}

TABLE II.

STYLES.

\begin{tabular}{|c|c|c|c|}
\hline No. of styles. & 2 & 3 & 4 \\
\cline { 1 - 3 } Short-styled & 0 & 1 & 0 \\
\cline { 2 - 3 } Long-styled & $6^{2}$ & 3 & I \\
\hline
\end{tabular}

The stigmas lobed in a definite manner were constricted into two, three, or four lobes, the exact proportion of each kind being indicated in the accompanying Table (I), and illustrated by Nos. I and 2 (Fig. 20).

1 One slightly so.

2 Of these one had two flat stigmas and another one stigma longer than the other. 
Mac $\mathrm{Nab}^{1}$ has recorded a bilobed stigma. In describing a specimen, he states: 'The whole of the flower is perfectly normal, except that the stigma is markedly bilobed. The ovary does not seem to consist of more carpels than usual.' The flowers, with the anomalous stigmas, had but a single style; a certain number of blossoms, however, were observed which possessed more than one; thus there were seen six cases of two styles, four of three, and one of four (Table II). It was often noticed that when the number of styles was more than one, these organs were shorter than is normally the case (Nos. 3 and 4, Fig. 20). It may also be stated that in cultivated plants of $P$. floribunda, a comparatively high proportion of flowers examined showed lobed stigmas; but in all cases a single style was present. It is also worthy of note that in these instances of lobed stigmas, excepting one flower in which the number of parts was normal throughout, there was an increase in the number of the members of each whorl. The exception had a two-lobed stigma, but the calyx, corolla, and androecium each had five component parts. Of the other cases the following held: $-\mathrm{C}_{9} \mathrm{Co}_{9} \mathrm{An}_{10}$ stigma two-lobed, $\mathrm{C}_{6} \mathrm{Co}_{6} \mathrm{An}_{6}$ stigma two-lobed, $\mathrm{C}_{6} \mathrm{Co}_{6} \mathrm{An}_{6}$ stigma irregularly lobed and somewhat peltate.

Comparing these numbers with what obtained in those flowers of $P$. vulgaris having lobed stigmas, it is found that in the latter plant the majority of such flowers had their normal number of sepals, \&c.; never was there a marked increase as in the case of $P$. floribunda.

It is true that the proportion of these variations in the style and stigma is very low : they are of interest, however, when the discussion as to the number of carpels present in the ovary is borne in mind.

It might be argued from these abnormalities that the ovary is composed of more than one carpel: but it has to be borne in mind that teratological evidence, taken by itself and without reference. to the facts of development, is, according to

1 Mac Nab, On some Abnormal Flowers of Primula. Proc. Roy. Dublin Soc., vol. ii, I $878-80$. 
many botanists, somewhat dangerous and apt to be misleading. The published evidence as to the development of the pistil

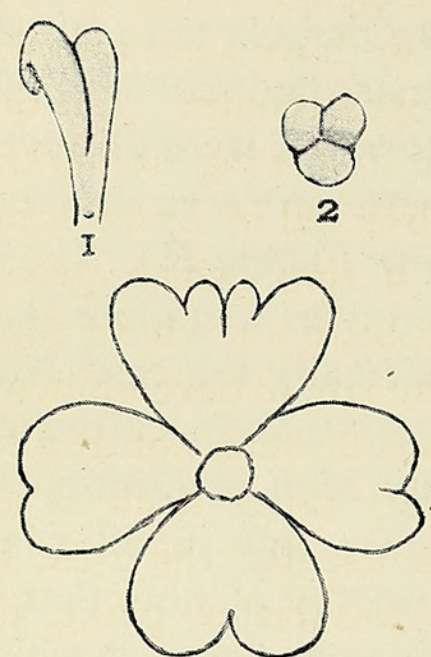

5

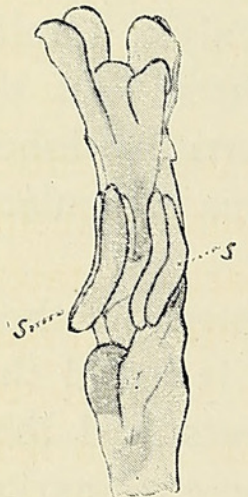

8

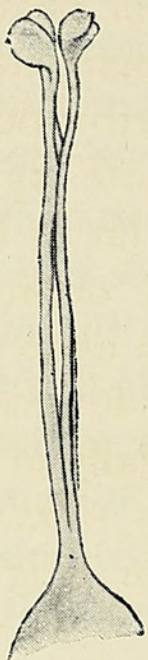

3

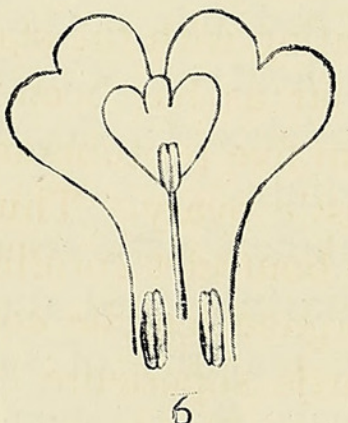

FIG. 20.

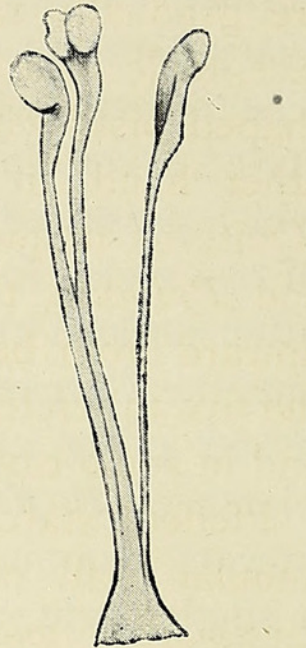

4

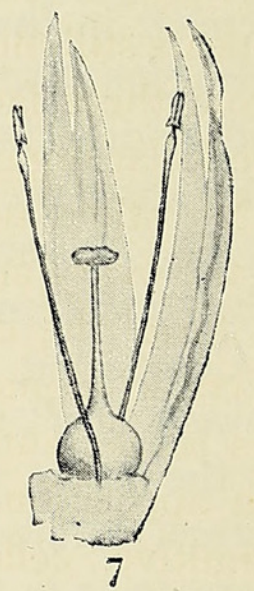

All the illustrations are of Primula vulgaris. I. Side view of a two-lobed stigma. 2. A three-lobed stigma viewed from above. 3. Part of a pistil showing two styles. 4. An ovary with three styles. 5. A flower with four petals, one of which is doubly lobed. 6. A blossom having a small petal more internally situated than the others, and showing one stamen carried up to the corolla throat. 7. Dissection of a flower with two free stamens inserted on the receptacle. 8. Pistil showing a curiously lobed stigma with two adnate stamens $(s)$.

may or may not lead to the conelusion that only one carpel is present.

Masters ${ }^{1}$, writing of Primula, states that 'On its (the re-

1 Masters, On some Points in the Morphology of the Primulaceae. Trans. Linn. Soc., Ser. 2, Bot., vol. i, I877. 


\section{of certain Species of Primula.}

ceptacle's) raised edge five small tubercles sometimes appear simultaneously, which are the carpels. These five tubercles are gradually raised from below by the lengthening of the receptacle in a tubular manner, so that we have soon a flaskshaped pistil with its narrow neck and open mouth.' On the other hand, in a footnote appear the following remarks: 'Quite as frequently, as far as I have observed in Lysimachia and Primula, the pistil originates as a ring, which grows upward from beneath so as to form a tube, upon whose edge the five tubercles are not formed till quite late in development, and in some cases, especially in monstrous flowers, not at all.'

Pfeffer ${ }^{1}$ states that in Glaux the ovary raises itself as an - annular wall of uniform height, as is usually the case in Lysimachia quadrifolia. As regards the latter plant, he observes that sometimes one sees three, rarely four or five, portions of the wall project as humps. This occasionally appears still more evidently in Primula elatior and P.chinensis. From these facts he concludes that one has here to do with five foliar organs alternating with the stamens.

No other author, as far as has been seen, makes mention of the ovary arising from five protuberances ultimately fusing to form the characteristic ovary: Thus Duchartre ${ }^{2}$ states: - Vers le moment où le bourrelet corollin se montre à la base des jeunes anthères, l'organe fémelle commence à manifester son apparition. La partie supérieure et centrale de la fleur primitive, celle qu'entoure l'androcée et qui possède une surface assez large, commence à se relever, dans toute sa circonférence, d'un leger bourrelet circulaire continu; ce bourrelet circonscrit un petit enfoncement dont le fond ne reste pas uni ni creux, mais se bosselle lui-même et un petit mamelon arrondi qui occupe le centre de toute la fleur.'

Payer ${ }^{3}$ writing about the development of Samolus Valerandi

1 Pfeffer, W., Zur Blüthenentwicklung der Primulaceen und Ampelideen. Pringsheim's Jahrb. f. wiss. Bot, vol. viii, p. 194.

2 Duchartre, Observations sur l'organogénie de la fleur et en particulier de l'ovaire chez les plantes à placenta central libre. Ann. des Sci. Nat., Bot., $3^{\boldsymbol{\theta}}$ sér., tom. ii, I 844 .

3 Payer, Traité d’Organogénie Comparée de la Fleur. Paris, I857. 
makes the following statements: 'Peu de temps après la naissance des étamines, le centre de la fleur se déprime et il en résulte une petite excavation, qui est l'origine du pistil. Cette petite excavation n'occupe pas tout le centre de la fleur; il y a entre elle et la base des étamines une sorte de chemin de halage sur lequel on voit bientôt poindre un bourrelet circulaire qui grandit rapidement, et forme une sorte de tuyau de cheminée au-dessous de l'excavation qui, de son côté, est devenue de plus en plus profonde.'

My own observations show that in the plants examined ${ }^{1}$ the ovary arises invariably as a ring of tissue, and nothing has been seen either in Primula or the other plants which could be interpreted as five carpels. Once only, in Anagallis arvensis, Linn., the top of a young ovary was seen to be somewhat crenated.

Up to the present, then, it appears from the facts of development that the tubular upgrowth is either a single carpel, or, if it represents a number of carpels, the rudiments are generally indistinguishable owing to the simultaneous upgrowth of the tissue between them. On the other hand, there are many points in favour of the ovary being multicarpellary in nature.

The increased number of styles and stigmas tends to show that there are present more than one carpel, and then the dehiscence of the capsules of many plants of the Order into five or ten teeth points in the same direction, or of the structure in question being derived phylogenetically from one with five carpels.

Again, if the other Orders of the Cohort to which the Primulaceae belong are examined, it is found that the Plumbaginaceae are characterized by the possession of five styles, which is in favour of the ovary of Primulaceae being. composed of five carpels.

The Myrsinaceae having but a single style do not afford evidence of a definite character.

1 Primula veris, Linn., Hottonia palustris, Linn., Glaux maritima, Linn., Anagallis arvensis, Linn., and Samolus Valerandi, Linn. 
Variations other than numerical. It was only to be expected that abnormalities, other than have been considered up to the present, would be seen during the examination of a large number of flowers.

It is proposed to mention them briefly now.

Primula veris, Linn. No striking monstrosities were observed in this plant. A few flowers were seen in which one member of a whorl, either calyx or corolla, was smaller than its fellows. More frequently the filament of a stamen was divided into a $\mathrm{Y}$-shaped structure, each branch bearing an anther.

Primula vulgaris, Huds. In 1898 the only other abnormalities seen were as follows. Single sepals or petals were sometimes (five instances) smaller than the others, and in one case the petals of a flower were in three distinct sizes.

The style varied much in length, thus the stigma in longstyled flowers was sometimes protruded out of the corolla tube, and sometimes was only just above the stamens. In the short-styled flowers two instances were noted in which the stigma was about level with the stamens.

1899. Monstrosities were much commoner this year. The corolla frequently had a petal lobed in the manner illustrated in No. 5) Fig. 20). The exact number of such instances was six, three cases occurring in the long-styled flowers, and three in the short. Of the former two specimens possessed six petals and one five; and of the latter one corolla had four petals, one five, and the other six.

Two flowers were seen in which one petal was inserted in front of another. No. 6 illustrates a similar peculiarity, but here the small and more internally placed petal was alternate: in this flower (No. 6, Fig 20) there was a further abnormality consisting in one stamen being carried up to the irregularly placed petal on a filament partly adnate to the corolla tube, thus forming a rough transition between the long and short-styled flowers. (It will be seen from the figure that the flower was of the long-styled type.) This particular blossom possessed six sepals, the numbers of the 
other parts were normal. The other instance of superposed petals showed no peculiarity in its androecium, and had five sepals, eight petals, and seven stamens.

No. 7 (Fig. 20) illustrates a portion of a very interesting short-styled flower which had eight sepals, eight petals, and ten stamens, eight of which were situated at the throat of the corolla and the other two inserted upon the receptacle. These two had long free filaments, so that their anthers were carried up to the level of the others.

A parallel instance to this was seen in another flower which had the normal number of sepals and petals but seven stamens, two of which were inserted lower down on the corolla tube and had long filaments. The pistil of this flower also was very abnormal. It was of a curious shape, broad and short; the stigma was lobed and the style was partly staminal, two very pronounced stamens being sessile upon it.

This is illustrated in No. 8.

The remaining abnormalities were less interesting, and consisted of sepals and petals being of an abnormal size, thus making the flower zygomorphic. Branched filaments of stamens were not uncommon, twenty instances being noted. The styles of some flowers were longer or shorter than is normally the case in the manner already pointed out above. 


\section{$2 \mathrm{BHL}$ Biodiversity Heritage Library}

Hill, T. G. 1902. "On variation in the flowers of certain species of Primula." Annals of botany 16, 317-326.

https://doi.org/10.1093/oxfordjournals.aob.a088875.

View This Item Online: https://www.biodiversitylibrary.org/item/233980

DOI: https://doi.org/10.1093/oxfordjournals.aob.a088875

Permalink: https://www.biodiversitylibrary.org/partpdf/318676

\section{Holding Institution}

Smithsonian Libraries

\section{Sponsored by}

Biodiversity Heritage Library

\section{Copyright \& Reuse}

Copyright Status: Not in copyright. The BHL knows of no copyright restrictions on this item.

This document was created from content at the Biodiversity Heritage Library, the world's largest open access digital library for biodiversity literature and archives. Visit BHL at https://www.biodiversitylibrary.org. 